\title{
Genetic diversity of Leptotrichia and description of Leptotrichia goodfellowii sp. nov., Leptotrichia hofstadii sp. nov., Leptotrichia shahii sp. nov. and Leptotrichia wadei sp. nov.
}

Correspondence Emenike R. K. Eribe emenike@odont.uio.no

\author{
Emenike R. K. Eribe, ${ }^{1}$ Bruce J. Paster, ${ }^{2,3}$ Dominique A. Caugant,, ${ }^{1,4}$ \\ Floyd E. Dewhirst, ${ }^{2,3}$ Verlyn K. Stromberg, ${ }^{5}$ George H. Lacy ${ }^{5}$ \\ and Ingar Olsen ${ }^{1}$ \\ ${ }^{1}$ Institute of Oral Biology, Dental Faculty, University of Oslo, POB 1052, Blindern, \\ N-0316 Oslo, Norway \\ ${ }^{2}$ Department of Molecular Genetics, The Forsyth Institute, 140 The Fenway, Boston, \\ MA 02115, USA \\ ${ }^{3}$ Department of Oral and Developmental Biology, Harvard School of Dental Medicine, Boston, \\ MA 02115, USA \\ ${ }^{4}$ Division for Infectious Disease Control, Norwegian Institute of Public Health, POB 4404, \\ Nydalen, N-0403 Oslo, Norway \\ ${ }^{5}$ Department of Plant Pathology, Physiology and Weed Science, Virginia Polytechnic Institute \\ and State University, Blacksburg, VA 24061-0330, USA
}

\section{INTRODUCTION}

Based on comparative analysis of 16S rRNA sequences, Leptotrichia is one of six genera in the family Fusobacteriaceae in the phylum Fusobacteria. The genus Leptotrichia contains Leptotrichia buccalis, the type species of the genus
(Hofstad, 1984), and two recently defined species, Leptotrichia trevisanii (Tee et al., 2001) and 'Leptotrichia amnionii' (Shukla et al., 2002). L. trevisanii was isolated from the blood of a man with acute myeloid leukaemia (Tee et al., 2001) and 'L. amnionii' from the amniotic fluid of a woman

Published online ahead of print on 21 November 2003 as DOI 10.1099/ijs.0.02819-0.

The GenBank/EMBL/DDBJ accession numbers for the $16 \mathrm{~S}$ rDNA sequences of L. hofstadii LB 23 ${ }^{\top}$, L. shahii LB $37^{\top}$, L. wadei LB $16^{\top}$ and L. goodfellowii LB 57 ${ }^{\top}$ are AY029803, AY029806, AY029802 and AY029807. 
after intrauterine fetal demise (Shukla et al., 2002). The closely related species 'Leptotrichia sanguinegens' (Hanff et al., 1995a) (='Leptotrichia microbii'; Hanff et al., 1995b) was recently transferred to a new genus Sneathia as Sneathia sanguinegens (Collins et al., 2001).

Leptotrichia species are large, fusiform, non-sporulating and non-motile rods with a Gram-negative-like cell wall (Hofstad \& Selvig, 1969). The primary habitat of Leptotrichia is the human oral cavity, where they are typically found in dental plaque (Hofstad \& Olsen, 2004). However, Leptotrichia has been also isolated from the normal flora of the periurethral region of healthy girls and the genitalia of women (Moore et al., 1976; Söderberg et al., 1979; Evaldson et al., 1980). L. buccalis or L. buccalis-like bacteria have occasionally been recovered from blood, mostly in immunocompromised patients with neutropenia and from endocarditis (Reig et al., 1985; Weinberger et al., 1991; Hammann et al., 1993; Messiaen et al., 1996; Vernelen et al., 1996; Patel et al., 1999).

The taxonomy of Leptotrichia has been somewhat vague. For example, L. buccalis has often been misclassified as species of Fusobacterium and Lactobacillus (Hamilton \& Zahler, 1957). Indeed, even within the genus Leptotrichia, there is significant heterogeneity in enzymic/biochemical reactions (Eribe et al., 2002) and in cellular fatty acid content (Hofstad \& Jantzen, 1982; Eribe et al., 2002). Furthermore, significant variation among 60 strains of Leptotrichia was observed in SDS-PAGE profiles of whole-cell proteins and RAPD patterns of DNA (Eribe \& Olsen, 2002). In the present study, these 60 strains were further analysed to examine their full taxonomic and phylogenetic diversity by using full-length $16 \mathrm{~S}$ rDNA sequencing, DNA-DNA hybridization and colony and cell morphology assessment.

\section{METHODS}

Bacteria. The 60 strains of Leptotrichia used, with their site of isolation and source, are listed in Table 1. The isolates originated from gingival/periodontal pockets of man, human saliva, dental plaque, supragingival calculus, human synovia, septic arthritis and unknown sources. They fulfilled the novel species requirements for different sources with respect to geography and ecology (Christensen et al., 2001). All isolates were received from well-recognized private or public culture collections in Europe and America where they had been characterized.

Cultivation of bacterial strains. The organisms were inoculated from frozen stock onto Columbia (AppliChem) agar or brain heart infusion (BHI) (AppliChem) agar plates supplemented with $5 \%$ human blood, $50 \mathrm{mg}$ haemin $\mathrm{ml}^{-1}$ (Sigma) and $5 \mathrm{mg}$ menadione $\mathrm{ml}^{-1}$ (Sigma). They were cultured anaerobically $\left(90 \% \mathrm{~N}_{2}, 5 \% \mathrm{H}_{2}\right.$ and $5 \% \mathrm{CO}_{2}$ ) at $37^{\circ} \mathrm{C}$ for $2-5$ days in evacuation jars (Anoxomat System, WS9000; Mart). After replating the cultures, single colonies were picked and subcultured anaerobically on Columbia blood agar plates at $37^{\circ} \mathrm{C}$ for $2-5$ days. After culturing, bacterial cells were harvested by centrifugation (11000 r.p.m.) for $5 \mathrm{~min}$ and stored at $-20{ }^{\circ} \mathrm{C}$ if not used immediately.

DNA extraction for 16S rDNA analysis. DNA was extracted according to the procedure of Popovic et al. (1993) with some modifications (Eribe \& Olsen, 2000). Bacterial DNA was resuspended in $100 \mu \mathrm{l}$ TE buffer $(10 \mathrm{mM}$ Tris/HCl, pH 8.0, $1 \mathrm{mM}$ EDTA) and its quality checked spectrophotometrically and by gel electrophoresis.

Amplification of 16S rDNA and purification of PCR products. The 16S rRNA genes from the examined strains were amplified under standardized conditions with the primers 9F forward and 1541R reverse (Table 2). PCR was performed in thin-walled tubes with a Perkin-Elmer 9700 thermocycler. One microlitre of the diluted $(1: 5)$ DNA template was added to a reaction mixture $(50 \mu \mathrm{l}$ final volume) containing $1 \times$ Taq 2000 reaction buffer, $2.5 \mathrm{mM}$ $\mathrm{MgCl}_{2}, 0 \cdot 8 \mu \mathrm{M}$ dNTPs, $400 \mathrm{nM}$ of each primer and $1 \mathrm{U}$ Taq 2000 polymerase (Stratagene) in buffer containing Taqstart antibody (Sigma). In a hot-start protocol, samples were preheated at $94{ }^{\circ} \mathrm{C}$ for 4 min followed by amplification under the following conditions: denaturation at $94{ }^{\circ} \mathrm{C}$ for $45 \mathrm{~s}$, annealing at $60^{\circ} \mathrm{C}$ for $45 \mathrm{~s}$ and extension for $1.5 \mathrm{~min}$ with an additional $1 \mathrm{~s}$ for each cycle. A total of 30 cycles was performed, followed by a final elongation step at $72{ }^{\circ} \mathrm{C}$ for $15 \mathrm{~min}$. The products of PCR amplification were examined by electrophoresis in a $1 \%$ agarose gel. DNA was stained with ethidium bromide and visualized under short-wavelength UV light. Amplified $16 \mathrm{~S}$ rRNA genes were purified with the Sequenase kit (Amersham Pharmacia) for partial sequencing and on Sephadex G-50 resin columns before full-length sequencing.

$16 S$ rDNA sequencing. Purified DNA from PCR was sequenced with an ABI Prism cycle-sequencing kit (BigDye Terminator cycle sequencing kit with AmpliTaq DNA polymerase FS; Perkin-Elmer). Quarter-dye chemistry was applied with $3 \cdot 2 \mu \mathrm{M}$ primers and $1.5 \mu \mathrm{l}$ PCR products in a final volume of $20 \mu \mathrm{l}$. Cycle sequencing was done with an ABI 9700 PCR machine with 25 cycles of denaturation at $96^{\circ} \mathrm{C}$ for $10 \mathrm{~s}$ and annealing and extension at $60^{\circ} \mathrm{C}$ for $4 \mathrm{~min}$. Purified DNA products were dried in a speed vac for $75 \mathrm{~min}$, resuspended in $3.2 \mu \mathrm{l}$ loading dye and denatured at $98^{\circ} \mathrm{C}$ for $2 \mathrm{~min}$. The denatured products were then kept on ice and, finally, $1.5 \mu \mathrm{DNA}$ was loaded into the $8 \%$ Long-Ranger polyacrylamide gel (FMC Bioproducts). Sequencing reactions were run on an ABI Prism 377 DNA sequencer.

Data analyses of 165 rDNA sequences. First, approximately 410 bases were sequenced to determine the identity or approximate phylogenetic position of the 60 strains. Using six additional sequencing primers (Table 2), full sequences (about 1500 bases) were then obtained for 11 representative strains, some of which represented putative novel species. For identification of the closest relatives, the sequences of the unrecognized strains were compared with the $16 \mathrm{~S}$ rRNA gene sequences of over 9000 bacteria in Paster and Dewhirst's database and 76000 sequences in the Ribosomal Data Project (RDP) (Cole et al., 2003). Similarity matrices were corrected for multiple base changes at single positions by the method of Jukes \& Cantor (1969). Phylogenetic trees were constructed by the neighbour-joining method of Saitou \& Nei (1987). Sequences were aligned using the MegAlign program (DNASTAR) and imported into TREECON, a software package for the Microsoft Windows environment, which was used for the construction and drawing of evolutionary trees (Van de Peer et al., 1996).

Nucleotide sequence accession numbers. The complete $16 \mathrm{~S}$ rRNA gene sequences of the novel species were deposited in 2001 in GenBank under the accession numbers listed in Fig. 1.

DNA-DNA relatedness assays. The $S_{1}$-nuclease procedure for the free-solution reassociation for DNA similarity assays was used for pairwise reactions (Johnson, 1994) with selected strains of Leptotrichia. All procedures, including DNA isolation, French pressure cell fragmentation, hybridization and $\mathrm{S}_{1}$-nuclease assays have been detailed elsewhere (Johnson, 1994). However, rather than labelling 
Table 1. Strains originally assigned as L. buccalis and 'L. pseudobuccalis' used in this study

Original assignments were derived from Eribe et al. (2002): LB, L. buccalis; LPB, 'L. pseudobuccalis'. Culture collections: ATCC, American Type Culture Collection, Manassas, VA, USA; VPI, Virginia Polytechnic Institute and State University, Blacksburg, VA, USA; CCUG, Culture Collection of Göteborg, Göteborg, Sweden. NK, Not known.

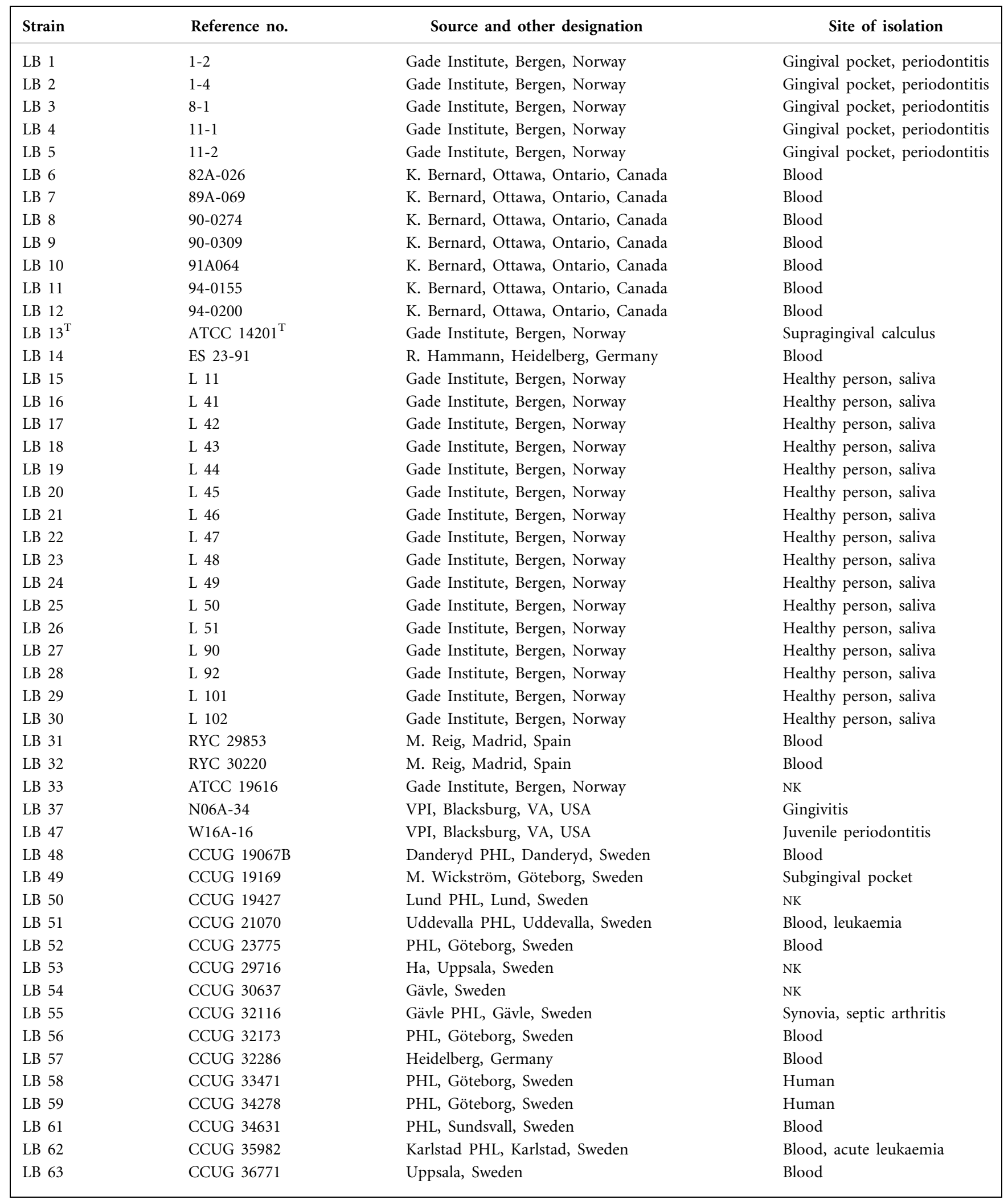


Table 1. cont.

\begin{tabular}{|llll|}
\hline Strain & Reference no. & Source and other designation & Site of isolation \\
\hline LB 64 & CCUG 36868 & Tromsø, Norway & Blood \\
LB 65 & CCUG 36980 & Skövde PHL, Skövde, Sweden & Blood \\
LB 66 & CCUG 38157 & PHLS, Halmstad, Sweden & Blood, leukaemia \\
LB 67 & CCUG 38343 & Lindköping, Sweden & Sputum \\
LPB 68 & CCUG 32006 & Sundsvall, Sweden & Blood \\
LPB 69 & CCUG 34137 & PHL, Danderyd, Sweden & Oral cavity \\
LB 70 & ATCC 23471 & G. Frostell strain 18, Sweden & Oral cavity \\
LB 71 & ATCC 23472 & G. Frostell strain 19, Sweden & Blood, pneumonia \\
LB 76 & CCUG 41699 & PHLS, Halmstad, Sweden & Blood, leukaemia \\
LB 77 & CCUG 42664 & PHL, Karlstad, Sweden & \\
\hline
\end{tabular}

the probe DNA chemically with ${ }^{125} \mathrm{I}$, the random primers method was used (Random Primers DNA labelling system; Invitrogen Life Technologies) to label DNA with $\left[\alpha_{-}{ }^{33}\right.$ P]dCTP (Perkin Elmer Life Sciences). The probe and target DNAs were reassociated at $66 \cdot 2 \pm 0 \cdot 5^{\circ} \mathrm{C}$ for $24 \mathrm{~h}$ for Leptotrichia DNA with a mean $\mathrm{G}+\mathrm{C}$ content of $29 \cdot 7 \mathrm{~mol} \%$ (Tee et al., 2001). Values for both homologous and heterologous reassociations were corrected for non-specific heteroduplex formation by control reactions with salmon sperm single-stranded DNA (0\% DNA relatedness) and were less than $10 \%$. Each reaction was repeated at least three times. The mean of all reactions was reported as percentage DNA-DNA relatedness. DNA from Erwinia amylovora ATCC 29780 (EA 110) was used as the outgroup.

Morphological studies. Cellular morphology of the novel species was determined by examining cells grown anaerobically at $37^{\circ} \mathrm{C}$ on Columbia or BHI blood agar plates. Light microscopy (LM) and transmission (TEM) and scanning (SEM) electron microscopy were used for characterization of cell morphology and ultrastructure. With LM, bacterial cells were also checked for motility in wet mounts and for Gram-staining.

\section{RESULTS AND DISCUSSION}

\section{$16 S$ rDNA sequencing}

Based on comparisons of nearly complete $16 \mathrm{~S}$ rDNA sequences, the phylogenetic relationships of the 60 Leptotrichia isolates revealed that there were four putative novel species (Fig. 1), namely Leptotrichia goodfellowii sp. nov. $\left(\right.$ LB $\left.57^{\mathrm{T}}\right)$, Leptotrichia hofstadii sp. nov. (LB $\left.23^{\mathrm{T}}\right)$, Leptotrichia shahii sp. nov. (LB $\left.37^{\mathrm{T}}\right)$ and Leptotrichia wadei sp. nov. $\left(\right.$ LB $\left.16^{\mathrm{T}}\right)$. Sequence database searches confirmed that these species were related, but clearly different from each other and from L. buccalis. Strains LB 06 and LB 11, which were essentially identical (Fig. 1), had $99 \cdot 6$ and $99 \cdot 7 \%$ sequence similarity to the recently proposed $L$. trevisanii (Tee et al., 2001).

L. wadei $\mathrm{LB} 16^{\mathrm{T}}$, from the saliva of a healthy man, clustered with a previously described strain, A39FD, that was isolated from subgingival plaque (Fig. 1). LB $16^{\mathrm{T}}$ had $94 \%$ sequence similarity to L. buccalis.

The type strains of $L$. hofstadii $\left(\mathrm{LB} 23^{\mathrm{T}}\right)$, L. shahii $\left(\mathrm{LB} 37^{\mathrm{T}}\right)$ and L. goodfellowii $\left(\mathrm{LB} 57^{\mathrm{T}}\right.$ ) each formed individual clusters that respectively showed 97,96 and $92 \%$ sequence similarity to $L$. buccalis. L. hofstadii $\mathrm{LB} 23^{\mathrm{T}}$, isolated from the saliva of a healthy man, clustered with a previously described strain (FAC5) that was isolated from dental plaque. L. shahii LB $37^{\mathrm{T}}$, from dental plaque of a gingivitis patient, clustered with DE081, a previously described phylotype from dental plaque. L. goodfellowii LB $57^{\mathrm{T}}$ was isolated from human blood. Leptotrichia isolates have repeatedly been recovered from cases of bacteraemia (Reig et al., 1985; Weinberger et al., 1991; Schwartz et al., 1995; Patel et al., 1999; Tee et al., 2001), suggesting that they may be involved in

Table 2. Primers used for amplification and sequencing of $16 \mathrm{~S}$ rRNA genes

\begin{tabular}{|lclcl|}
\hline Primer & Orientation & Function & Position $(\mathbf{b p})^{*}$ & \multicolumn{1}{c|}{ Sequence $\left(\mathbf{5}^{\prime} \mathbf{- 3}^{\prime}\right)$} \\
\hline $9 \mathrm{~F}$ & Forward & PCR & $9-27$ & GAGTTTGATYCTGGCTCAG \\
$338 \mathrm{~F}$ & Forward & Sequencing & $339-358$ & CTCCTACGGGAGGCAGCAGT \\
$531 \mathrm{R}$ & Reverse & Sequencing & $509-527$ & TACCGCGGCTGCTGGCAC \\
$789 \mathrm{~F}$ & Forward & Sequencing & $789-806$ & TAGATACCCYGGTAGTCC \\
$926 \mathrm{R}$ & Reverse & Sequencing & $896-915$ & CCGTCWATTCMTTTGAGTTT \\
$1099 \mathrm{~F}$ & Forward & Sequencing & $1099-1113$ & GCAACGAGCGCAACC \\
$1193 \mathrm{R}$ & Reverse & Sequencing & $1175-1194$ & ACGTCATCCCCACCTTCCTC \\
$1541 \mathrm{R}$ & Reverse & PCR & $1526-1541$ & GAAGGAGGTGWTCCARCCGCA \\
\hline
\end{tabular}

${ }^{\star}$ Numbered relative to Escherichia coli (Woese et al., 1983). 


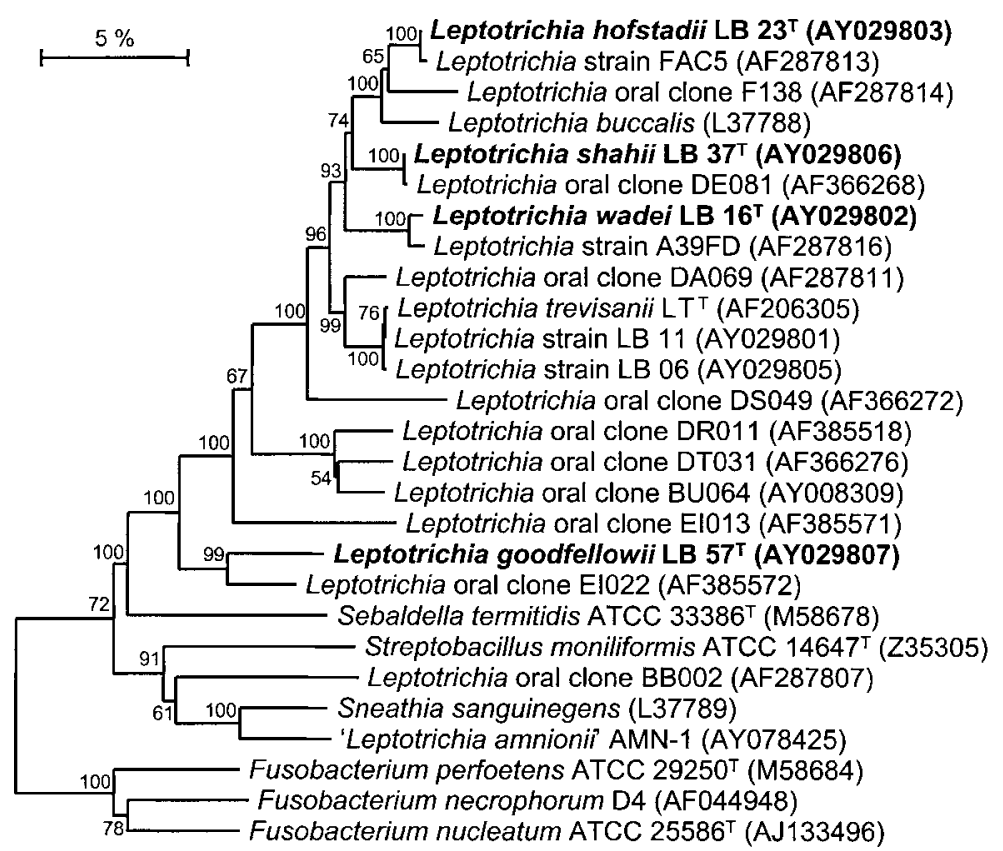

Fig. 1. Phylogenetic tree of full-length $16 \mathrm{~S}$ rRNA gene sequences showing positions of L. goodfellowii sp. nov. LB $57^{\top}$, L. hofstadii sp. nov. LB $23^{\top}$, L. shahii sp. nov. LB $37^{\top}$ and $L$. wadei sp. nov. LB $16^{\top}$. Strains LB 6 and LB 11 have almost identical sequences (99.6 and $97.0 \%$, respectively) to that of $L$. trevisanii $\mathrm{LT}^{\top}$. Bar, $5 \%$ difference in nucleotide sequences as estimated using the correction of Jukes \& Cantor (1969). Distances are determined by measuring the lengths of the horizontal lines connecting two sequences. Numbers at branching points are bootstrap percentages. GenBank accession numbers are given.

non-oral infections of the body. For example, Leptotrichia has been associated with endocarditis (Duperval et al., 1984; Hammann et al., 1993), liver abscess (Messiaen et al., 1996) and neutropenia in immunocompromised hosts (Reig et al., 1985; Baquero et al., 1990; Patel et al., 1999).

Close relatives of L. goodfellowii were phylotypes EI022 and EI013 (Fig. 1), which had been derived from the subgingival pocket of a healthy subject. Each of these phylotypes likely represents additional species.

Clone DA069 (Fig. 1) is essentially identical to a novel Leptotrichia-like isolate (accession no. AF182944) from a neutropenic patient (Patel et al., 1999), indicating that the source of this species is indeed the oral cavity.

'L. sanguinegens' ( = 'L. microbii') (Hanff et al., 1995a, b) has recently been reclassified as Sneathia sanguinegens (Collins et al., 2001). Our data (Fig. 1) suggest that 'L. amnionii' would be better assigned to the genus Sneathia than to Leptotrichia.

\section{DNA-DNA relatedness}

Phylogenetic relationships of the putative novel species were confirmed by using DNA-DNA relatedness. It has been suggested that differences of $>1-2 \%$ between RNA sequences are sufficient to characterize bacteria as taxonomically different. In addition, those organisms that differ by more than $3 \%$ in sequence comparisons rarely display more than $60 \%$ DNA-DNA relatedness (Stackebrandt \& Goebel, 1994). The differences between the sequences of the designated novel species and that of L. buccalis were greater than $3 \%$.

The $S_{1}$-nuclease method of free-solution reassociation for DNA similarity assays has been recommended for definition of bacterial species (Steigerwalt et al., 1976; Johnson, 1994; Stackebrandt \& Goebel, 1994). Six relatedness groups within the genus Leptotrichia were defined (Table 3). These relatedness groups correlated well with phylogenetic clustering (Fig. 1). The phylogenetic tree (not shown) generated from the DNA-DNA relatedness results of the seven labelled (LB 6, LB $13^{\mathrm{T}}$, LB 16, LB 23, LB $37^{\mathrm{T}}$, LB $57^{\mathrm{T}}$ and L. trevisanii $\mathrm{LT}^{\mathrm{T}}$ ) and two unlabelled (LB 11 and EA 110) strains was divided into seven clusters (Table 3 ). One cluster consisted of LB 6, LB 11 and L. trevisanii $\mathrm{LT}^{\mathrm{T}}$. 16S rRNA gene sequencing had grouped LB 6 and LB 11 together (Fig. 1) and LB 16 and strain A39FD. DNA-DNA relatedness of more than $70 \%$ is a key definition for strains belonging to the same species (Johnson, 1973; Steigerwalt et al., 1976; Wayne et al., 1987; Stackebrandt \& Goebel, 1994). Strains LB 6 and LB 11 showed more than $70 \%$ relatedness with $L$. trevisanii (Table 3 ) and should be considered strains of this species. There was complete agreement between the $16 \mathrm{~S}$ rRNA gene sequences and DNA-DNA relatedness results for strains LB $23^{\mathrm{T}}$, LB $37^{\mathrm{T}}$ and LB $57^{\mathrm{T}}$. Based on these results, separate species designation of the putative novel species is warranted. The type strain of L. buccalis constituted a cluster by itself and E. amylovora formed an outgroup, as expected.

The phylogenetic diversity supported previous phenotypic and genotypic data from the same isolates examined for enzymic/biochemical reactions, cellular fatty acid content, SDS-PAGE patterns of whole-cell proteins and RAPD profiles (Eribe et al., 2002; Eribe \& Olsen, 2002). Key characteristics that differentiate these species are listed in Table 4. Dendrograms based on $70 \%$ similarity of fingerprints from SDS-PAGE of whole-cell protein and RAPD with primers OPA 3 and OPA 5 (Dendron computerassisted gel analysis) showed that the novel species were clearly different from each other and from L. buccalis (results 
Table 3. Percentage DNA-DNA relatedness among Leptotrichia species

Species-level $(\geqslant 70 \%)$ groupings are boxed. E. amylovora was included as an outgroup.

\begin{tabular}{|c|c|c|c|c|c|c|c|}
\hline \multirow[t]{2}{*}{ Source of labelled DNA } & \multicolumn{7}{|c|}{ DNA-DNA relatedness with unlabelled DNA from: } \\
\hline & 1 & 2 & 3 & 5 & 6 & 7 & 8 \\
\hline 2. L. trevisanii $\mathrm{LT}^{\mathrm{T}}$ & $42 \cdot 8$ & $100 \cdot 0$ & $91 \cdot 4$ & $38 \cdot 7$ & $36 \cdot 3$ & $37 \cdot 4$ & $4 \cdot 1$ \\
\hline 3. Strain LB 6 & $40 \cdot 3$ & $82 \cdot 9$ & $100 \cdot 0$ & $45 \cdot 7$ & $45 \cdot 4$ & $40 \cdot 5$ & $5 \cdot 2$ \\
\hline 4. Strain LB 11 & $36 \cdot 4$ & $69 \cdot 5$ & $71 \cdot 3$ & $36 \cdot 5$ & $38 \cdot 4$ & $33 \cdot 0$ & $3 \cdot 1$ \\
\hline 6. L. hofstadii $\mathrm{LB} 23^{\mathrm{T}}$ & $36 \cdot 3$ & $34 \cdot 6$ & $32 \cdot 6$ & $35 \cdot 9$ & $100 \cdot 0$ & $39 \cdot 0$ & $4 \cdot 6$ \\
\hline 7. L. shahii LB $37^{\mathrm{T}}$ & $24 \cdot 5$ & $25 \cdot 0$ & $35 \cdot 4$ & $52 \cdot 6$ & $24 \cdot 7$ & $100 \cdot 0$ & $2 \cdot 7$ \\
\hline 8. L. goodfellowii LB $57^{\mathrm{T}}$ & $5 \cdot 5$ & $7 \cdot 5$ & $9 \cdot 3$ & $9 \cdot 3$ & $8 \cdot 7$ & $10 \cdot 8$ & $100 \cdot 0$ \\
\hline 9. Erwinia amylovora EA 110 & $-4 \cdot 3$ & $2 \cdot 2$ & $2 \cdot 9$ & $2 \cdot 8$ & $-0 \cdot 6$ & $2 \cdot 3$ & $1 \cdot 6$ \\
\hline
\end{tabular}

Table 4. Salient characteristics of Leptotrichia species

Strains: 1, L. buccalis LB $13^{\mathrm{T}}$; 2, L. goodfellowii LB $57^{\mathrm{T}}$; 3, L. hofstadii LB $23^{\mathrm{T}}$; 4, L. shahii LB $37^{\mathrm{T}}$; 5 , L. wadei LB $16^{\mathrm{T}}$. Data were partly derived from Eribe et al. (2002). All strains show optimum growth at $37^{\circ} \mathrm{C}$ and are positive for catalase and aesculin. Predominant cellular fatty acids were detected with the Sherlock system; values are percentages of total fatty acids. DMA, Dimethyl acetal; ECL, equivalent chain-length.

\begin{tabular}{|c|c|c|c|c|c|}
\hline Characteristic & 1 & 2 & 3 & 4 & 5 \\
\hline Number of strains & 26 & 3 & 7 & 1 & 11 \\
\hline Number of clones & 0 & 1 & 0 & 1 & 0 \\
\hline $25^{\circ} \mathrm{C}$ & + & - & - & + & - \\
\hline $42^{\circ} \mathrm{C}$ & + & - & - & - & - \\
\hline \multicolumn{6}{|l|}{ ID 32 A results: } \\
\hline Arginine dihydrolase & - & + & - & - & - \\
\hline$\alpha$-Galactosidase & + & - & - & - & - \\
\hline$\beta$-Galactosidase & - & + & - & - & - \\
\hline$\beta$-Galactosidase-6-phosphate & + & - & + & - & - \\
\hline$\alpha$-Glucosidase & + & - & + & + & + \\
\hline Raffinose fermentation & + & - & - & - & - \\
\hline Alkaline phosphatase & + & + & + & - & - \\
\hline Arginine arylamidase & - & + & - & - & - \\
\hline Leucine arylamidase & - & + & - & - & - \\
\hline Tyrosine arylamidase & + & - & - & - & - \\
\hline Histidine arylamidase & - & + & - & - & - \\
\hline Profile & 4616400100 & 2111412001 & 0612400000 & 0420000000 & 0410000000 \\
\hline \multicolumn{6}{|l|}{ Saturated straight-chain fatty acids: } \\
\hline $14: 0$ & 10 & 14 & 6 & 9 & 7 \\
\hline $16: 0$ & 39 & 41 & 48 & 32 & 45 \\
\hline \multicolumn{6}{|l|}{ Hydroxy fatty acids: } \\
\hline $3-\mathrm{OH}-14: 0$ or $15: 0$ DMA & 7 & 9 & 9 & 5 & 8 \\
\hline
\end{tabular}


not shown). Particularly, DNA-DNA relatedness and SDSPAGE showed good congruence that supported Vauterin et al. (1993), emphasizing the fitness of protein electrophoresis in bacterial classification. Also, the 16S rRNA phylogenetic tree corresponded well with the SDS-PAGE dendrogram. Thus, our studies demonstrate the value of polyphasic taxonomy for establishing novel bacterial species (Vandamme et al., 1996).

Morphological studies using LM, SEM and TEM showed that the four novel species had several features in common. They were Gram-negative, non-spore-forming and nonmotile rods. Cells were arranged in pairs, some slightly curved, others in chains joined by flattened ends. Electron micrographs of ultrathin sections revealed elongated cells with a cell-wall architecture typical of Gram-negative bacteria. A double plasma membrane layer, a single electron-dense (intermediate) layer, a double outer layer and scale-like protrusions were observed (Fig. 2a, c, e and g). A cross-section of the cell showed storage granules. SEM of L. goodfellowii demonstrated short rods, varying in length from 2 to $4 \mu \mathrm{m}$ and from 0.3 to $0.6 \mu \mathrm{m}$ in width, with one end tapered (Fig. 2b). SEM of $L$. hofstadii revealed long rods, $7 \cdot 5-15 \mu \mathrm{m}$ long and $0 \cdot 5-0 \cdot 9 \mu \mathrm{m}$ wide, with one end tapered (Fig. 2d). L. shahii exhibited long rods, $7 \cdot 5$ $17 \cdot 5 \mu \mathrm{m}$ long and $0 \cdot 5-0 \cdot 9 \mu \mathrm{m}$ wide, with one end tapered (Fig. 2f), and $L$. wadei had short rods, $2 \cdot 5-10 \mu \mathrm{m}$ long and $0 \cdot 3-0 \cdot 6 \mu \mathrm{m}$ wide, with one end tapered (Fig. $2 \mathrm{~h}$ ).

Based on the results from enzymic/biochemical reactions, cellular fatty acid analysis, SDS-PAGE of whole-cell proteins and RAPD (Eribe et al., 2002; Eribe \& Olsen, 2002) and those of the current study related to $16 \mathrm{~S}$ rDNA sequencing and DNA-DNA relatedness, four previously unrecognized Leptotrichia species could be established. However, it is likely that additional species of Leptotrichia are present in the oral cavity. In sequence analysis of clones of $16 \mathrm{~S}$ rDNA genes amplified directly from sites in the oral cavity (Paster et al., 2001; Becker et al., 2002), several not-yet-cultivated species were detected that did not cluster with known species or those described in the present study (Fig. 1).

\section{Description of Leptotrichia goodfellowii sp. nov.}

Leptotrichia goodfellowii (good.fel'low.i.i. N.L. gen. n. goodfellowii of Goodfellow, named in honour of Mike Goodfellow, for his contributions to microbial systematics).

After 2-6 days of anaerobic incubation at $37^{\circ} \mathrm{C}$, colonies on Columbia or BHI agar plates supplemented with $5 \%$ human blood, haemin and menadione are $0 \cdot 8-2 \cdot 0 \mathrm{~mm}$ in diameter, speckled, convex, irregular, pink in the periphery and greyish light brown in the rest of the colony. They have a glistening surface, are opaque, dry and $\beta$-haemolytic. Catalase positive and aesculin weakly positive. Oxidase and indole are not produced. Colonies grow best anaerobically and sparsely aerobically. Growth occurs at $37^{\circ} \mathrm{C}$ but not at 25 or $42^{\circ} \mathrm{C}$; optimal temperature for growth is $37^{\circ} \mathrm{C}$. Gram-negative, non-spore-forming, non-motile rods. Cells are arranged in pairs, some slightly curved, others in chains joined by flattened ends. Arginine dihydrolase, $\beta$-galactosidase, $\beta$-glucosidase, $N$-acetyl- $\beta$-glucosaminidase, alkaline phosphatase, arginine arylamidase, leucine arylamidase and histidine arylamidase are produced. Mannose is fermented. Additional phenotypic properties are listed in Table 4. Isolated from human blood.

The type strain is LB $57^{\mathrm{T}}\left(=\right.$ CCUG $\left.32286^{\mathrm{T}}=\mathrm{CIP} 107915^{\mathrm{T}}\right)$.

\section{Description of Leptotrichia hofstadii sp. nov.}

Leptotrichia hofstadii (hof.stad'i.i. N.L. gen. n. hofstadii of Hofstad, named in honour of Tor Hofstad, for his contributions to Leptotrichia taxonomy).

After 2-6 days of anaerobic incubation at $37^{\circ} \mathrm{C}$, colonies on Columbia or BHI agar plates supplemented with $5 \%$ human blood, haemin and menadione are $0.5-1.8 \mathrm{~mm}$ in diameter. They have a glistening and granular surface, are opaque, dry and $\beta$-haemolytic. Older colonies can be up to $4 \cdot 0-6 \cdot 5 \mathrm{~mm}$, circular, convex, entire (some are irregular and lobate) and greyish in colour with a dark central spot. Catalase positive and aesculin weakly positive. Oxidase and indole are not produced. Colonies grow best anaerobically and sparsely aerobically. Growth occurs at $37^{\circ} \mathrm{C}$ but not at 25 or $42^{\circ} \mathrm{C}$; optimal temperature is $37^{\circ} \mathrm{C}$. Gram-negative, non-spore-forming, non-motile rods. Cells are arranged in pairs, some slightly curved, others in chains joined by flattened ends. $\beta$-Galactosidase- 6 -phosphate, $\alpha$-glucosidase, $\beta$-glucosidase and alkaline phosphatase are produced. Mannose is fermented. Additional phenotypic properties are listed in Table 4. Isolated from the saliva of a healthy person.

The type strain is LB $23^{\mathrm{T}}\left(=\right.$ CCUG $\left.47504^{\mathrm{T}}=\mathrm{CIP} 107917^{\mathrm{T}}\right)$.

\section{Description of Leptotrichia shahii sp. nov.}

Leptotrichia shahii (shah'i.i. N.L. gen. n. shahii of Shah, named in honour of Haroun N. Shah, a Trinidad-born microbiologist, for his contributions to microbiology).

After 2-6 days of anaerobic incubation at $37^{\circ} \mathrm{C}$, colonies on Columbia or BHI agar plates supplemented with $5 \%$ human blood, haemin and menadione are $1.0-1.5 \mathrm{~mm}$ in diameter, very filamentous to rhizoid or convoluted, palespeckled and greyish in colour, with a dark central spot in old colonies. These are opaque, semi-dry in consistency and non-haemolytic. Catalase positive and aesculin weakly positive. Oxidase and indole are not produced. Colonies grow best anaerobically and sparsely aerobically. Growth occurs at 25 and $37^{\circ} \mathrm{C}$ but not at $42^{\circ} \mathrm{C}$; optimal temperature is $37^{\circ} \mathrm{C}$. Gram-negative, non-spore-forming, non-motile rods. Cells are arranged in pairs, some slightly curved, others in chains joined by flattened ends. $\alpha$-Glucosidase and $\alpha$ arabinosidase are produced. Additional phenotypic properties are listed in Table 4. Isolated from a patient with gingivitis. 

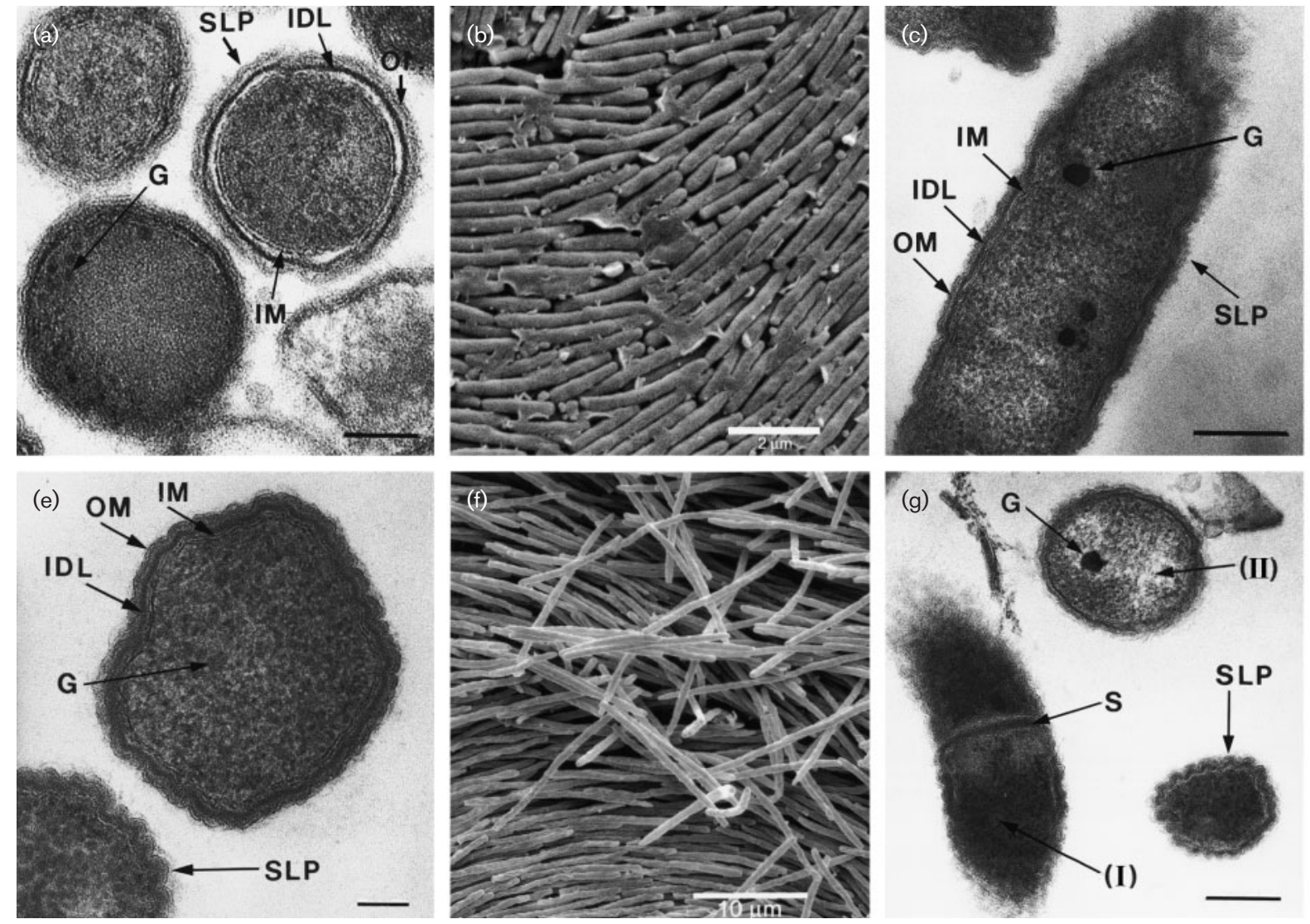

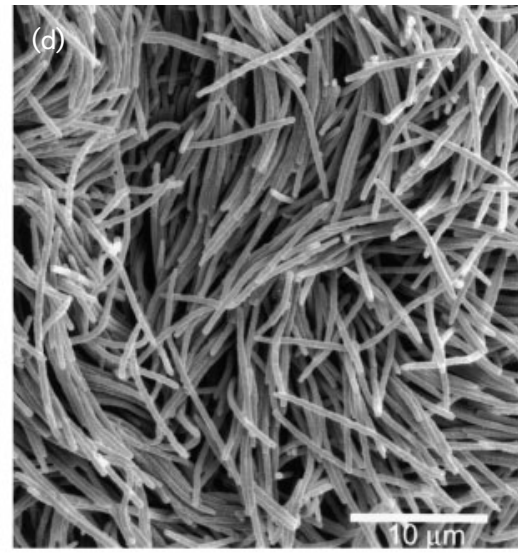

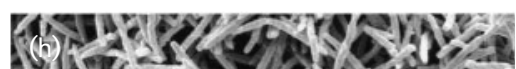

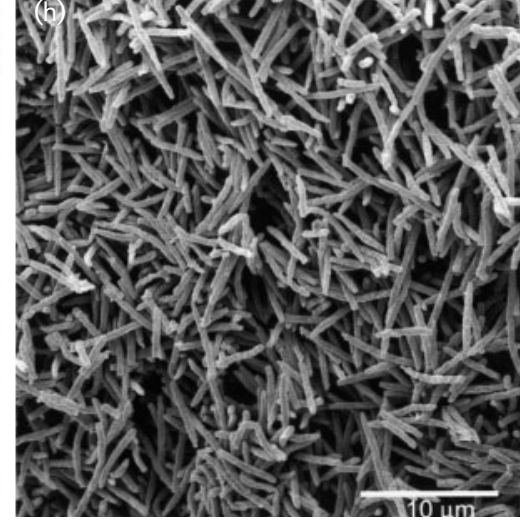

Fig. 2. TEM ( $a, c, e$ and $g$ ) and SEM (b, $d, f$ and $h$ ) of cells of novel Leptotrichia species from anaerobic cultures on Columbia blood agar grown at $37^{\circ} \mathrm{C}$ for 48 h. (a), (c), (e) and (g) Cross-sectional views of cells of L. goodfellowii sp. nov. LB $57^{\top}$ (a), L. hofstadii sp. nov. LB $23^{\top}$ (c), L. shahii sp. nov. LB $37^{\top}(\mathrm{e})$ and L. wadei sp. nov. LB $16^{\top}(\mathrm{g})$. In (g), cells are visible in both a longitudinal (I) and a cross-sectional (II) view. G, Granule; IDL, intermediate dense layer; IM, inner cytoplasmic membrane; OM, outer membrane; S, septum; SLP, scale-like protrusion. Bars, 0.1 (a, e) and 0.25 (c, g) $\mu \mathrm{m}$. (b), (d), (f) and (h) Cells from colonies of L. goodfellowii sp. nov. LB $57^{\top}$ (b), L. hofstadii sp. nov. LB $23^{\top}$ (d), L. shahii sp. nov. LB $37^{\top}$ (f) and L. wadei sp. nov. LB $16^{\top}(h)$ showing short $(b, h)$ and long $(d, f)$ rods. Bars, $2(b)$ and $10(d, f, h) \mu m$. 
The type strain is $\mathrm{LB} 37^{\mathrm{T}}$ ( = CCUG $47503^{\mathrm{T}}=$ VPI N06A$34^{\mathrm{T}}=$ CIP $107916^{\mathrm{T}}$ ).

\section{Description of Leptotrichia wadei sp. nov.}

Leptotrichia wadei (wade'i. N.L. gen. n. wadei of Wade, named in honour of William G. Wade, for his contributions to microbiology).

After 2-6 days of anaerobic incubation at $37^{\circ} \mathrm{C}$, colonies on Columbia or BHI agar plates supplemented with $5 \%$ human blood, haemin and menadione are $0.5-3.0 \mathrm{~mm}$ in diameter, convex, sparsely filamentous to irregular and greyish brown in colour, with a dark central spot in old colonies. The surface appearance is glistening and smooth with a rough edge. Colonies are opaque, dry in consistency and $\beta$-haemolytic. Aesculin and catalase are positive. Oxidase and indole are not produced. Growth occurs best anaerobically and sparsely aerobically at $37^{\circ} \mathrm{C}$ but not at 25 or $42^{\circ} \mathrm{C}$. Gram-negative, non-spore-forming, non-motile rods. Cells are arranged in pairs, some slightly curved, others in chains joined by flattened ends. $\alpha$-Glucosidase and $\beta$ glucosidase are produced. Additional phenotypic properties are listed in Table 4. Isolated from the saliva of a healthy person.

The type strain is $\operatorname{LB} 16^{\mathrm{T}}\left(=\mathrm{CCUG} 47505^{\mathrm{T}}=\mathrm{CIP} 107918^{\mathrm{T}}\right)$.

\section{ACKNOWLEDGEMENTS}

We are grateful to W. E. C. Moore (deceased) and L. V. H. Moore, Virginia Polytechnic Institute and State University, Blacksburg, VA, USA, to E. Falsen, CCUG Göteborg, Sweden, and to T. Hofstad, The Gade Institute, Bergen, Norway, for their donations of strains. Thanks are also due to T. Alvestad and A.-M. Klem, Division of Infectious Control, Norwegian Institute of Public Health, Oslo, and to S. K. Boches and J. L. Galvin, Forsyth Institute, Boston, MA, USA, for their assistance with $16 \mathrm{~S}$ rDNA sequencing, to R. Hars and S. Stølen, Institute of Oral Biology, Dental Faculty, University of Oslo, Norway, for their help with TEM and SEM, respectively, and to Grete Bergaust and Per Gran, Institute of Oral Biology, for their assistance with pictures. This work was financed in part by the Dental Faculty, University of Oslo, Norway, and by grant DE11443 from the National Institute of Dental and Craniofacial Research.

\section{REFERENCES}

Baquero, F., Fernandez, J., Dronda, F., Erice, A., Perez de Oteiza, J., Requera, J. A. \& Reig, M. (1990). Capnophilic and anaerobic bacteremia in neutropenic patients: an oral source. Rev Infect Dis $\mathbf{1 2}$ (Suppl. 2), S157-S160.

Becker, M. R., Paster, B. J., Leys, E. J., Moeschberger, M. L., Kenyon, S. G., Galvin, J. L., Boches, S. K., Dewhirst, F. E. \& Griffen, A. L. (2002). Molecular analysis of bacterial species associated with childhood caries. J Clin Microbiol 40, 1001-1009.

Christensen, H., Bisgaard, M., Frederiksen, W., Mutters, R., Kuhnert, P. \& Olsen, J. E. (2001). Is characterization of a single isolate sufficient for valid publication of a new genus or species? Proposal to modify Recommendation 30b of the Bacteriological Code (1990 Revision). Int J Syst Evol Microbiol 51, 2221-2225.
Cole, J. R., Chai, B., Marsh, T. L. \& 8 other authors (2003). The Ribosomal Database Project (RDP-II): previewing a new autoaligner that allows regular updates and the new prokaryotic taxonomy. Nucleic Acids Res 31, 442-443.

Collins, M. D., Hoyles, L., Tornqvist, E., von Essen, R. \& Falsen, E. (2001). Characterization of some strains from human clinical sources which resemble "Leptotrichia sanguinegens": description of Sneathia sanguinegens sp. nov., gen. nov. Syst Appl Microbiol 24, 358-361.

Duperval, R., Béland, S. \& Marcoux, J. A. (1984). Infective endocarditis due to Leptotrichia buccalis: a case report. Can Med Assoc J 130, 422-424.

Eribe, E. R. \& Olsen, I. (2000). Strain differentiation in Bacteroides fragilis by RAPD and Dendron computer-assisted gel analysis. APMIS 108, 676-684.

Eribe, E. R. K. \& Olsen, I. (2002). SDS-PAGE of whole-cell proteins and random amplified polymorphic DNA (RAPD) analyses of Leptotrichia isolates. Microb Ecol Health Dis 14, 193-202.

Eribe, E. R. K., Hofstad, T. \& OIsen, I. (2002). Enzymatic/biochemical and cellular fatty acid analyses of Leptotrichia isolates. Microb Ecol Health Dis 14, 137-148.

Evaldson, G., Carlström, G., Lagrelius, A., Malmborg, A. S. \& Nord, C. E. (1980). Microbiological findings in pregnant women with premature rupture of the membranes. Med Microbiol Immunol 168, 238-297.

George, W. L., Kirby, B. D., Sutter, V. L., Citron, D. M. \& Finegold, S. M. (1981). Gram-negative anaerobic bacilli: their role in infection and patterns of susceptibility to antimicrobial agents. II. Littleknown Fusobacterium species and miscellaneous genera. Rev Infect Dis 3, 599-626.

Hamilton, R. D. \& Zahler, S. A. (1957). A study of Leptotrichia buccalis. J Bacteriol 73, 386-393.

Hammann, R., Iwan, A., Brachmann, J., Keller, K. \& Werner, A. (1993). Endocarditis caused by a Leptotrichia buccalis-like bacterium in a patient with a prosthetic aortic valve. Eur J Clin Microbiol Infect Dis 12, 280-282.

Hanff, P. A., Rosol-Donoghue, J.-A., Spiegel, C. A., Wilson, K. H. \& Moore, L. H. (1995a). Leptotrichia sanguinegens sp. nov., a new agent of postpartum and neonatal bacteremia. Clin Infect Dis 20, 237-239.

Hanff, P. A., Rosol-Donoghue, J.-A., Spiegel, C. A., Wilson, K. H. \& Moore, L. H. (1995b). Sneathia sanguinegens. NCBI Taxonomy Browser. http://www.ncbi.nlm.nih.gov/Taxonomy/Browser/ wwwtax.cgi?id $=40543$

Hofstad, T. (1984). Genus III. Leptotrichia Trevisan 1879, $138^{\mathrm{AL}}$. In Bergey's Manual of Systematic Bacteriology, vol. 1, pp. 637-641. Edited by N. R. Krieg \& J. G. Holt. Baltimore: Williams \& Wilkins.

Hofstad, T. \& Jantzen, E. (1982). Fatty acids of Leptotrichia buccalis: taxonomic implications. J Gen Microbiol 128, 151-153.

Hofstad, T. \& Olsen, I. (2004). Fusobacterium and Leptotrichia. In Topley and Wilson's Microbiology and Microbial Infections, 10th edn. Edited by P. Murray \& P. Boriello. London: Edward Arnold (in press).

Hofstad, T. \& Selvig, K. A. (1969). Ultrastructure of Leptotrichia buccalis. J Gen Microbiol 56, 23-26.

Johnson, J. L. (1973). Use of nucleic-acid homologies in the taxonomy of anaerobic bacteria. Int J Syst Bacteriol 23, 308-315.

Johnson, J. L. (1994). Similarity analysis of DNAs. In Methods for General and Molecular Bacteriology, pp. 655-682. Edited by P. Gerhardt, R. G. E. Murray, W. A. Wood \& N. R. Krieg. Washington, DC: American Society for Microbiology.

Jukes, T. H. \& Cantor, C. R. (1969). Evolution of protein molecules. In Mammalian Protein Metabolism, pp. 21-132. Edited by H. N. Munro. New York: Academic Press. 
Messiaen, T., Lefebvre, C. \& Geubel, A. (1996). Hepatic abscess likely related to Leptotrichia buccalis in an immunocompetent patient. Liver 16, 342-343.

Moore, W. E. C., Johnson, J. L. \& Holdeman, L. V. (1976). Emendation of Bacteroidaceae and Butyrivibrio and descriptions of Desulfomonas gen. nov. and ten new species in the genera Desulfomonas, Butyrivibrio, Eubacterium, Clostridium, and Ruminococcus. Int J Syst Bacteriol 26, 238-252.

Paster, B. J., Boches, S. K., Galvin, J. L., Ericson, R. E., Lau, C. N., Levanos, V. A., Sahasrabudhe, A. \& Dewhirst, F. E. (2001). Bacterial diversity in human subgingival plaque. J Bacteriol 183, 3770-3783.

Patel, J. B., Clarridge, J., Schuster, M. S., Waddington, M., Osborne, J. \& Nachamkin, I. (1999). Bacteremia caused by a novel isolate resembling Leptotrichia species in a neutropenic patient. J Clin Microbiol 37, 2064-2067.

Popovic, T., Bopp, C. A., Olsvik, Ø. \& Kiehlbauch, J. A. (1993). Ribotyping in molecular microbiology. In Diagnostic Molecular Microbiology, pp. 573-584. Edited by D. H. Persing, T. F. Smith, F. C. Tenover \& T. J. White. Washington, DC: American Society for Microbiology.

Reig, M., Baquero, F., Garcia-Campello, M. \& Loza, E. (1985). Leptotrichia buccalis bacteremia in neutropenic children. J Clin Microbiol 22, 320-321.

Saitou, N. \& Nei, M. (1987). The neighbor-joining method: a new method for reconstructing phylogenetic trees. Mol Biol Evol 4, 406-425.

Schwartz, D. N., Schable, B., Tenover, F. C. \& Miller, R. A. (1995). Leptotrichia buccalis bacteremia in patients treated in a single bone marrow transplant unit. Clin Infect Dis 20, 762-767.

Shukla, S. K., Meier, P. R., Mitchell, P. D., Frank, D. N. \& Reed, K. D. (2002). Leptotrichia amnionii sp. nov., a novel bacterium isolated from the amniotic fluid of a woman after intrauterine fetal demise. J Clin Microbiol 40, 3346-3349.
Söderberg, G., Lindberg, A. A. \& Nord, C. E. (1979). Bacteroides fragilis in acute salpingitis. Infection 7, 226-230.

Stackebrandt, E. \& Goebel, B. M. (1994). Taxonomic note: a place for DNA-DNA reassociation and 16S rRNA sequence analysis in the present species definition in bacteriology. Int J Syst Bacteriol 44, 846-849.

Steigerwalt, A. G., Fanning, G. R., Fife-Asbury, M. A. \& Brenner, D. J. (1976). DNA relatedness among species of Enterobacter and Serratia. Can J Microbiol 22, 121-137.

Tee, W., Midolo, P., Janssen, P. H., Kerr, T. \& Dyall-Smith, M. L. (2001). Bacteremia due to Leptotrichia trevisanii sp. nov. Eur J Clin Microbiol Infect Dis 20, 765-769.

Vandamme, P., Pot, B., Gillis, M., de Vos, P., Kersters, K. \& Swings, J. (1996). Polyphasic taxonomy, a consensus approach to bacterial systematics. Microbiol Rev 60, 407-438.

Van de Peer, Y., Nicolaï, S., De Rijk, P. \& De Wachter, R. (1996). Database on the structure of small ribosomal subunit RNA. Nucleic Acids Res 24, 86-91.

Vauterin, L., Swings, J. \& Kersters, K. (1993). Protein electrophoresis and classification. In Handbook of New Bacterial Systematics, pp. 251-280. Edited by M. Goodfellow \& A. G. O'Donnell. London: Academic Press.

Vernelen, K., Mertens, I., Thomas, J., Vandeven, J., Verhaegen, J. \& Verbist, L. (1996). Bacteremia with Leptotrichia buccalis: report of a case and review of the literature. Acta Clin Belg 51, 265-270.

Wayne, L. G., Brenner, D. J., Colwell, R. R. \& 9 other authors (1987). Report of the ad hoc committee on reconciliation of approaches to bacterial systematics. Int J Syst Bacteriol 37, 463-464.

Weinberger, M., Wu, T., Rubin, M., Gill, V. J. \& Pizzo, P. A. (1991). Leptotrichia buccalis bacteremia in patients with cancer: report of four cases and review. Rev Infect Dis 13, 201-206.

Woese, C. R., Gutell, R., Gupta, R. \& Noller, H. F. (1983). Detailed analysis of the higher-order structure of the 16S-like ribosomal ribonucleic acids. Microbiol Rev 47, 621-669. 